\title{
STUDI TRANSFORMASI GOETIT MENJADI HEMATIT SECARA MEKANOKIMIA UNTUK BENEFISIASI BIJIH BESI LATERIT
}

\author{
Study of Goethite-to-Hematite Transformation by Mechanochemical \\ Method for Lateritic Iron Ore Beneficiation
}

\author{
SURIYANTO BAKRI dan EDY SANWANI \\ Program Studi Teknik Metalurgi, Fakultas Pertambangan dan Perminyakan, \\ Institut Teknologi Bandung \\ Jalan Ganesha No. 10 Bandung 40132, Indonesia \\ e-mail: antobakrixp@gmail.com
}

\begin{abstract}
ABSTRAK
Sumberdaya dan cadangan bijih besi laterit Indonesia sangat melimpah sehingga memberi potensi untuk dimanfaatkan sebagai alternatif bahan baku pembuatan baja, mengingat kebutuhan besi baja tiap tahunnya meningkat. Pada penelitian ini dilakukan transformasi fasa goetit menjadi hematit secara mekanokimia untuk meningkatkan kandungan Fe pada bijih besi laterit. Percobaan secara mekanokimia dilakukan dengan menvariasikan waktu penggerusan $5-50$ jam, $20-50 \%$ persen volume mill dan jenis bola penggerus. Hasil karakterisasi menunjukkan bahwa bijih besi laterit asal Pulau Sebuku, Kalimantan Selatan bersifat ferromagnetik yang didominasi oleh goetit $(\mathrm{FeOOH})$ dan maghemit $\left(\gamma \mathrm{Fe}_{2} \mathrm{O}_{3}\right)$ dengan kadar $\mathrm{Fe} 42,68 \%$. Transformasi fasa goetit menjadi hematit dan maghemit menjadi magnetit secara sempurna terjadi setelah 50 jam penggerusan, pada persen volume mill terbaik $50 \%$, dan jenis media bola penggerus baja dengan kadar Fe 53,03\%. Distribusi ukuran partikel D $9054,30 \mathrm{~nm}$. Penggerusan secara mekanokimia berpengaruh pada sifat kemagnetan bijih besi laterit yang semula dengan nilai intensitas medan magnet 6,23 emu/gram naik menjadi 9,55 emu/gram.
\end{abstract}

Kata kunci: bijih besi laterit, transformasi fasa, mekanokimia, benefisiasi.

\begin{abstract}
The resources and reserves of Indonesian laterite iron ore are very abundant considering the increasing need of steel each year, such the resources is potential to be utilized as an alternative for steelmaking raw materials. The transformation of goethite phase into hematite is conducted mechanochemically in term of increasing the Fe content within lateritic iron ore. The mechanochemical experiments were carried out by varying the grinding time from 5 - 50 hours, percent volume of 20 - 50\% mill and the type of ball crushing. Characterization results show that the lateritic iron ore from Sebuku Island, South Kalimantan is ferromagnetic and is dominated by goethite $(\mathrm{FeOOH})$ and maghemite $\left(\mathrm{yFe} \mathrm{O}_{3}\right)$ with $42.68 \%$ Fe. The goethite transformation to hematite and maghemite to magnetite occurs completely after 50-hour grinding, at 50-percent best milling, using 53.03\% iron-containing steel grinding ball. The particle size distribution of $D_{90}$ is $54.30 \mathrm{~nm}$. Mechanochemistry grinding affect on the magnitude of the lateritic iron ore magnetism with the magnetic field intensity value of $6.23 \mathrm{emu} /$ gram increases to $9.55 \mathrm{emu} /$ gram.
\end{abstract}

Keywords: laterite iron ore, phase transformation, mechanochemical, beneficiation. 


\section{PENDAHULUAN}

Komsumsi baja nasional pada 2016 meningkat tajam sebesar 12,67 juta ton sedang kapasitas produksi hanya sebesar 5,4 juta dan diperkirakan akan mencapai 19,12 juta ton pada 2025 sementara industri dalam negeri hanya akan mampu memproduksi 10 juta ton sehingga akan terjadi kekurangan pasokan baja yang akan dipenuhi dengan membuka impor baja (Kementerian Perindustrian, 2017). Sejak 2014 sampai saat ini, industri baja nasional kalah bersaing dengan baja impor yang harganya lebih murah. Kondisi ini terjadi karena bahan baku produk berupa bijih besi yang kadar besinya memenuhi syarat 100 persen masih tergantung kepada impor. Hal ini disebabkan oleh ketidakmampuan pengusahaan bijih besi dalam negeri memenuhi kebutuhan tersebut, sementara potensi bijih besi baik sumberdaya maupun cadangan sangat melimpah (Suratman, 2017).

Sumber daya bijih besi laterit tercatat sebesar $3.921,8$ juta ton dan cadangannya sebesar 736,9 juta ton, tersebar di Kalimantan Selatan, Sulawesi Selatan, Sulawesi Tenggara, Maluku Utara dan Papua Barat (Pusat Sumber Daya Geologi, 2016). Bijih besi laterit merupakan hasil pelapukan sehingga banyak didominasi oleh mineral-mineral goetit dan mengandung nikel. Kadar bijih besi laterit juga bervariasi dan dapat ditingkatkan kadarnya dengan berbagai macam teknologi peningkatan kadar (Pardiarto, 2011).

Bijih besi laterit memiliki kandungan besi rendah yaitu antara 39,8 - 55,2\% serta kandungan logam-logam pengotor seperti aluminium, silika, nikel, krom, kobal, mangan dan kandungan air yang tinggi. Karakteristik seperti itu menjadikan bijih besi laterit hampir belum dapat dimanfaatkan dalam industri besi-baja yang umumnya membutuhkan kadar besi antara $60-69 \%$ (Garg, 2014).

Goetit merupakan oksida besi yang terhidrasi di dalam bijih besi laterit sehingga sering disebut hydrated iron oxide. Ikatan kimia besi $\mathrm{Fe}_{2} \mathrm{O}_{3}$ dengan air kristal $\mathrm{H}_{2} \mathrm{O}$ menyebabkan goetit sulit untuk diolah secara langsung sehingga kandungan mineral goetit yang cukup dominan tersebut memerlukan metode pendahuluan atau pre-treatment sebelum dilakukan pemisahan antara mineral bersifat magnetik dengan mineral tidak bersifat magnetik.

Dalam kurun lima tahun terakhir, penelitian untuk menghasilkan partikel $\mathrm{Fe}_{2} \mathrm{O}_{3}$ berukuran nanometer telah menjadi subyek sejumlah penelitian (Iwasaki $d k k .$, 2013). Salah satu metode yang digunakan yaitu mengubah fasa goetit menjadi hematit dan atau magnetit. Metode ini disebut metode mekanokimia, yaitu memadukan reaksi kimia dengan gerakan mekanik dalam satu proses (Welham, 1998). Transformasi langsung $\alpha-F e O O H$ menjadi $\alpha-\mathrm{Fe}_{2} \mathrm{O}_{3}$ secara mekanokimia dengan reaksi $\boldsymbol{\alpha}-\mathrm{FeOOH} \rightarrow \boldsymbol{\alpha}-\mathrm{Fe}_{2} \mathrm{O}_{3}+\mathrm{H}_{2} \mathrm{O}$ (Lemine, 2014). Untuk menghasilkan partikel nano $\mathrm{Fe}_{2} \mathrm{O}_{3}$ telah digunakan umpan berupa besi murni, sintesis goetit, dan bubuk goetit. Oleh karena itu pada penelitian ini dilakukan metode mekanokimia sebagai pre-treatment untuk mengubah fasa goetit menjadi hematit dan atau magnetit pada bijih besi laterit.

Tujuan penelitian ini adalah mengubah mineral goetit menjadi hematit dan atau magnetit sehingga kadar Fe dapat meningkat dengan menentukan variabel terbaik terhadap waktu penggerusan, volume mill dan jenis media bola penggerus. Di samping itu, juga untuk mengetahui pengaruh penggerusan secara mekanokimia terhadap perubahan fasa, kadar Fe, reduksi ukuran dan sifat kemagnetan bijih besi laterit.

\section{METODE}

\section{Bijih besi laterit}

Bahan baku yang digunakan pada percobaan ini adalah bijih besi laterit asal Pulau Sebuku, Kalimantan Selatan. Percobaan dibagi menjadi dua tahap yaitu tahap preparasi percontoh dan tahap penggerusan secara mekanokimia. Secara rinci keseluruhan tahap percobaan dapat dilihat pada Gambar 1.

\section{Karakterisasi}

Karakterisasi percontoh menggunakan analisis $X$-ray Diffraction (XRD) merek Rigaku yang berfungsi untuk mengetahui jenis kandungan mineral, X-ray fluorescence (XRF) merek Rigaku berfungsi untuk mengetahui kadar mineral, Scanning Electron Microscope /Energi- 
dispersive detector (SEM-EDS) mapping merek Jeol berfungsi untuk mengetahui penyebaran unsur-unsur, Particle Size Analyzer merek Beckman Coulter berfungsi untuk mengetahui distribusi ukuran partikel dan Vibrating Sample Magnetometer (VSM) merek VSM250 berfungsi untuk mengetahui sifat kemagnetan.

\section{Eksperimen}

Preparasi dimulai dengan melakukan homogenisasi terhadap bijih besi laterit mentah (raw ore) dan dikeringkan pada suhu $100{ }^{\circ} \mathrm{C}$ selama 24 jam untuk menghilangkan kadar airnya, homogenisasi dan ditimbang. Percontoh sebanyak 150 gram kemudian digerus dengan pelumat bola (ball mill) selama 10 menit, ditimbang dan diayak pada ayakan berukuran 65, 100, 140, 200 dan 325 mesh mengacu pada standar ASTM, (American Standard for Testing Material) sehingga didapatkan $\mathrm{P}_{80}$ (Gambar 2). Selanjutnya dilakukan pemercontohan dengan metode spliter untuk penggerusan secara mekanokimia.

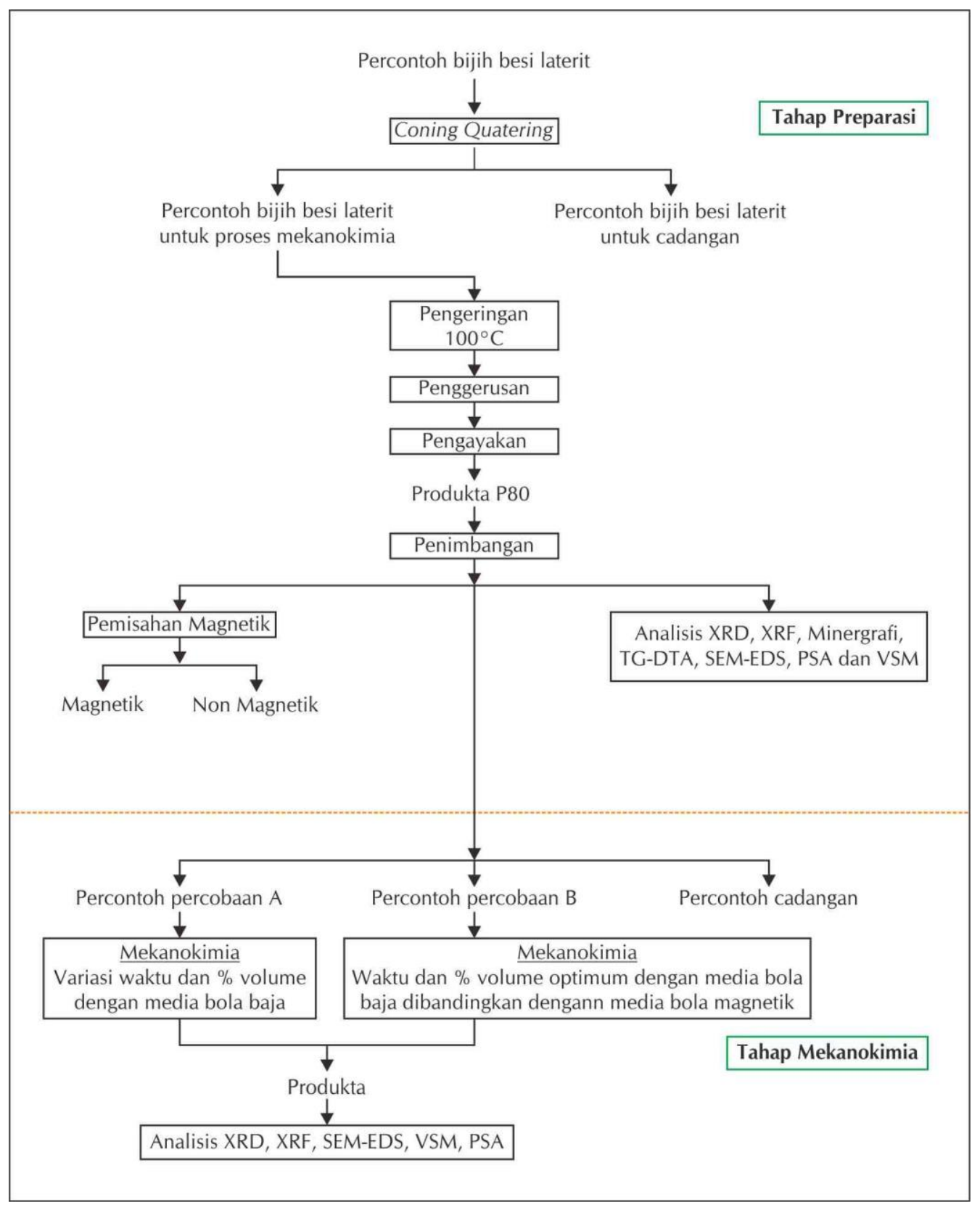

Gambar 1. Diagram alir percobaan transformasi fasa secara mekanokimia 


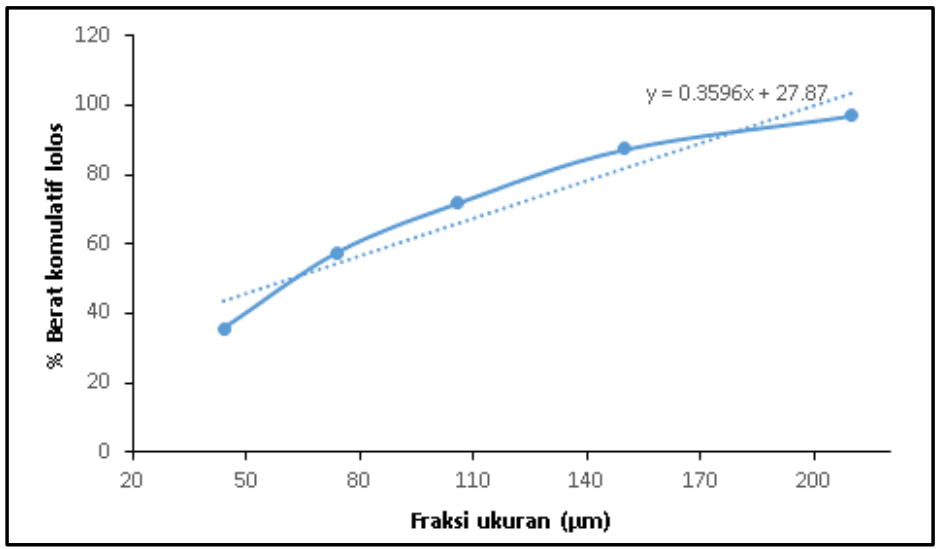

Gambar 2. Hasil analisis ayak percontoh

Percobaan penggerusan secara mekanokimia menggunakan planetarry ball mill (PBM) pada kecepatan 30\% dari kecepatan maksimum. Perbandingan berat umpan dengan media penggerus adalah 1:8, serta dilakukan variasi variabel terhadap waktu penggerusan dan persen volume muatan mill. Hasil terbaik variasi waktu dan volume muatan mill selanjutnya dilakukan percobaan perbandingan antara media bola baja dengan media bola keramik.

\section{HASIL DAN PEMBAHASAN}

\section{Karakteristik Bijih Besi Laterit Asal Pulau Sebuku, Kalimantan Selatan}

Karakteristik umum bijih besi laterit ini diperoleh dari tahap karakterisasi menggunakan beberapa analisis. Dari hasil pengujian XRD diketahui bahwa percontoh mengandung mineral goetit dan maghemit. Hal ini didukung oleh hasil analisis XRF yang menunjukkan bahwa unsur Fe mendominasi percontoh. Grafik XRD dan data XRF secara berurutan dapat dilihat pada Gambar 3 dan Tabel 1. Analisis mineralogi dengan mikroskopik bijih dan SEM-EDS mapping juga dilakukan sebagai referensi hasil yang sudah ada. Hasil mineralogi terlihat adanya mineral goetit, hematit, magnetit, dan mineral non logam sedangkan maghemit tidak terlihat, hal ini diperkirakan karena analisis XRD menggabungkan mineral berdasarkan sistem kristalnya. Mineral-mineral ini tampak terikat dengan mineral non logam (Gambar 4). Hasil SEM-EDS mapping terlihat bahwa keberadaan unsur Fe mendominasi percontoh dan diikuti oleh unsur $\mathrm{Al}$ dan $\mathrm{Si}$ yang saling terikat (Gambar 5).

Tabel 1. Hasil analisis XRF bijih besi laterit

\begin{tabular}{rcccc}
\hline Unsur & $\mathrm{Fe}$ & $\mathrm{Al}$ & $\mathrm{Si}$ & $\mathrm{Ni}$ \\
\hline Kadar $\%$ & 42,68 & 4,72 & 1,1 & 0,75 \\
\hline
\end{tabular}

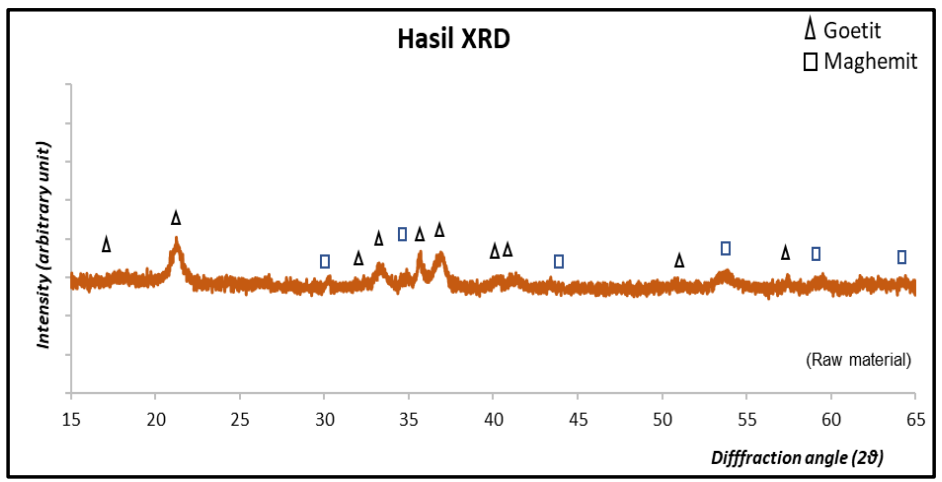

Gambar 3. Data hasil XRD percontoh bijih besi laterit mentah 


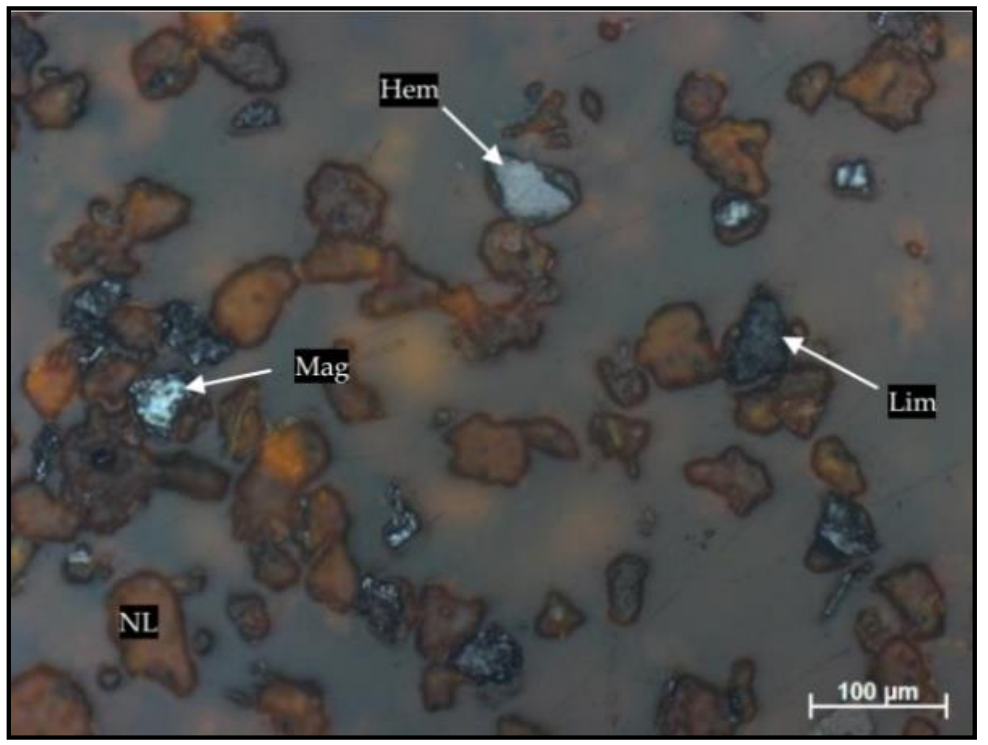

Gambar 4. Fotomikrograf sayatan poles bijih besi laterit mentah -200\#. Tampak hematit (Hem), magnetit (Mag) dan limonit (Lim) yang terikat dengan mineral non-logam (NL).

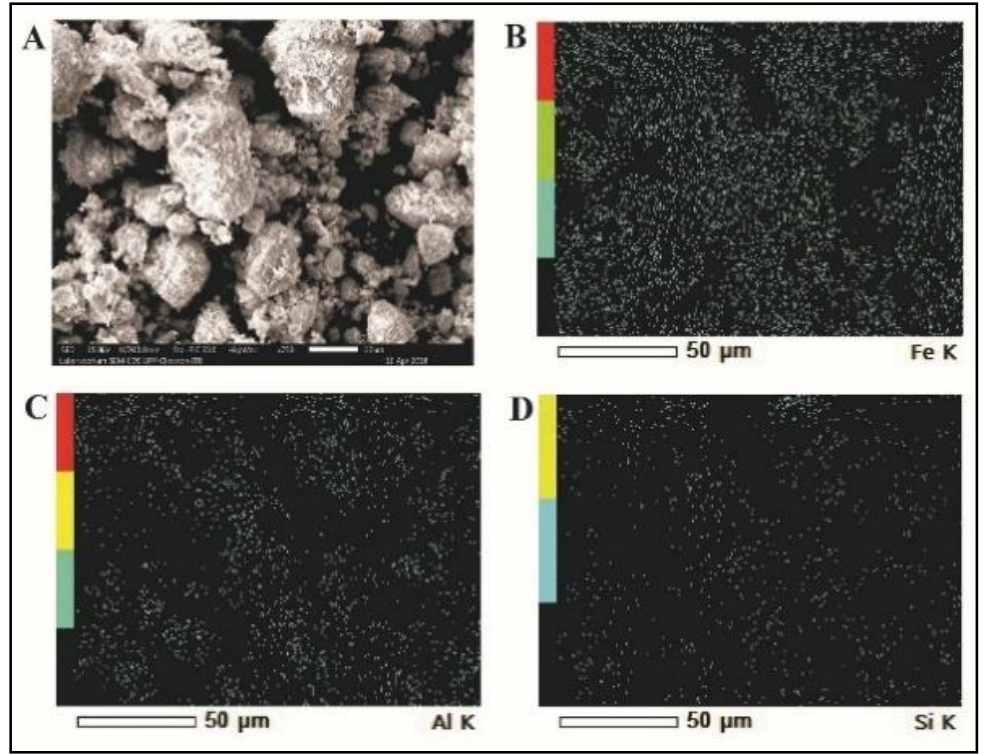

Gambar 5. Hasil SEM-EDS mapping bijih besi laterit mentah. (A) Foto SEM, (B) Foto keberadaan unsur Fe, (C) Foto keberadaan unsur AI, (D) Foto keberadaaan unsur Si

Dilakukan juga analisis VSA untuk mengetahui sifat kemagnetan percontoh bijih besi laterit. Hasil analisis memperlihatkan bahwa percontoh bijih besi laterit asal Pulau Sebuku bersifat ferromagnetik dengan nilai magnetisasi sebesar 6,23 emu/gram. Sifat ferromagnetik percontoh juga dibuktikan dari hasil analisis Suseptibilitas dengan nilai 41,22 x $10^{-6} \mathrm{~m}^{3} / \mathrm{kg}$ dengan frekuensi devinden $3.45 \%$ (Gambar 6).

\section{Pengaruh Waktu Penggerusan Terhadap Perubahan Fasa, Peningkatan Kadar, Reduksi Ukuran dan Sifat Kemagnetan}

Pengaruh waktu penggerusan secara mekanokimia terhadap perubahan fasa pada bijih besi laterit ditunjukkan pada Gambar 7 .

Bijih besi laterit mentah didominasi oleh goetit dan maghemit. Saat digerus selama 5 
jam belum terlihat perubahan intensitas puncak yang signifikan di antara kedua mineral. Setelah 20 jam penggerusan mulai terjadi perubahan intesitas puncak diantara kedua mineral begitu juga setelah 35 jam penggerusan. Puncak-puncak mineral goetit mulai menurun dan melebar. Hal yang sama terjadi pada puncak-puncak maghemit yang mulai menurun dan melebar. Diperkirakan sebagian mineral goetit sudah bertransformasi menjadi hematit dan maghemit menjadi magnetit walaupun belum terdeteksi oleh XRD. Hal ini terjadi karena bijih besi laterit mengalami dehidrasi, deformasi, dan fragmentasi kristal (González, Sagarzazu dan Villalba, 2000). Setelah penggerusan 50 jam puncak-puncak goetit dan maghemit menghilang sedangkan puncak-puncak hematit dan magnetit muncul dengan intensitas yang tinggi serta muncul puncak mineral pengotor berupa silika.

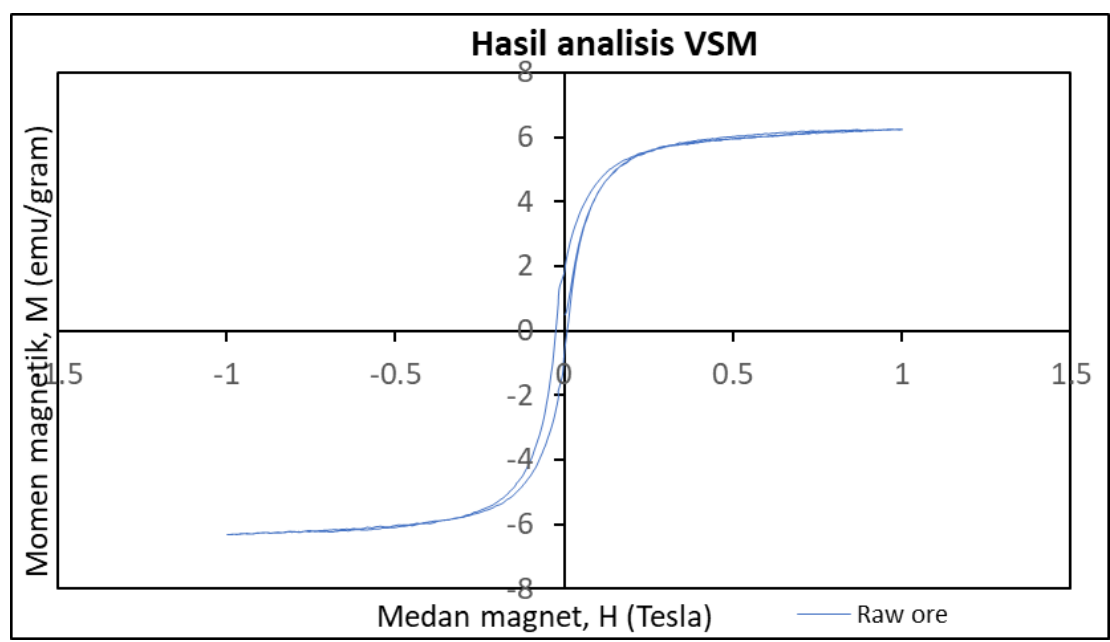

Gambar 6. Hasil analisis VSM percontoh bijih besi laterit mentah

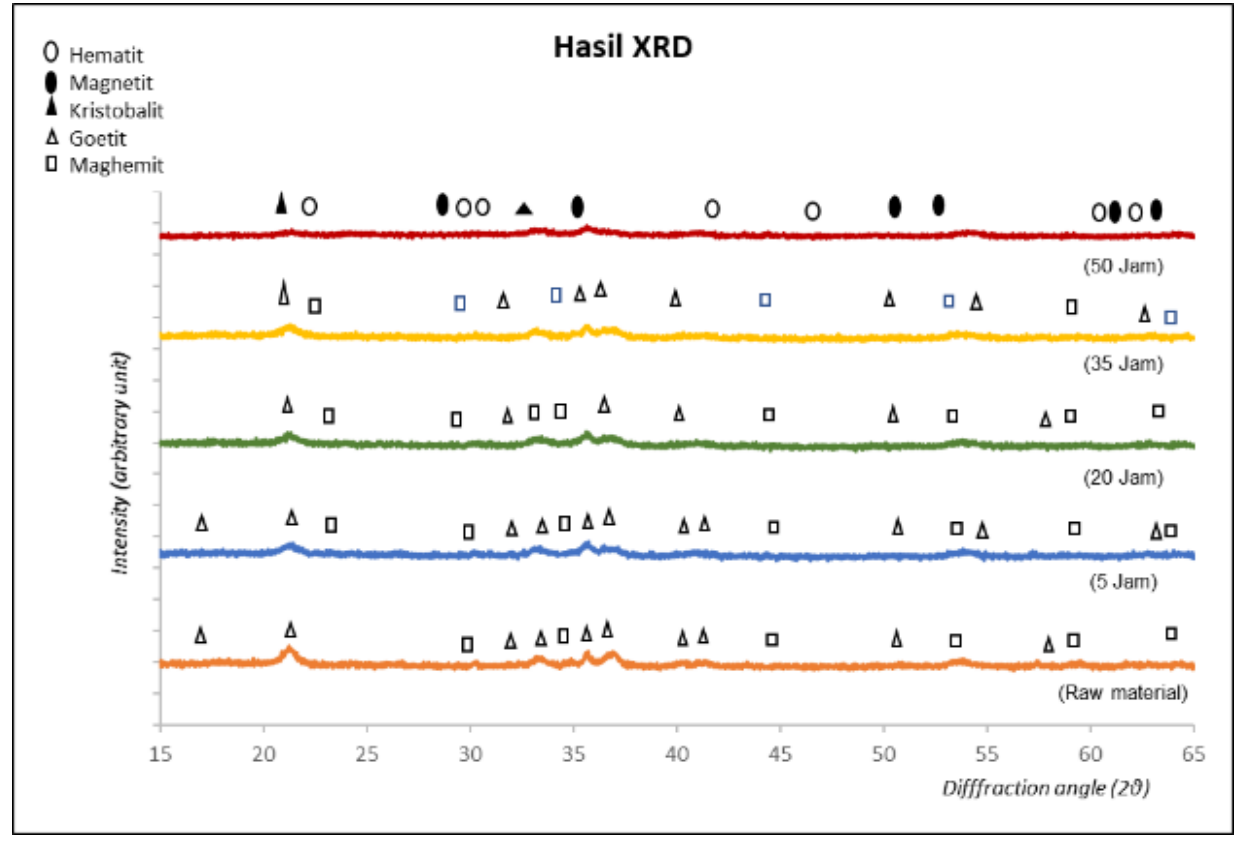

Gambar 7. Hasil XRD bijih besi laterit sebelum dan sesudah penggerusan secara mekanokimia 
Hasil XRF terhadap waktu penggerusan tercantum pada Gambar 8. Terlihat bahwa semakin lama waktu penggerusan, kadar Fe semakin meningkat. Semakin lama waktu penggerusan maka temperatur penggerusan juga akan meningkat (Suryanarayana, 2001). Hal ini ada hubungannya dengan suhu panas yang ditimbulkan, semakin tinggi suhu semakin tinggi kadar Fe yang diakibatkan oleh terjadinya transformasi fasa baik sebagian maupun seluruhnya. Waktu penggerusan menyebabkan terjadinya liberasi antara mineral berharga dengan mineral pengotornya.

Gambar 9 menunjukkan bahwa semakin lama waktu penggerusan, semakin kecil ukuran partikel yang dihasilkan. Ukuran partikel yang semakin kecil menyebabkan waktu transformasi fasa semakin cepat. Hal ini disebabkan karena pada ukuran partikel yang lebih kecil tersimpan energi yang lebih sehingga hanya sedikit membutuhkan suhu untuk menghasilkan phase-transition (Chen, 2013). Analisis Particle Size Analyzer terhadap ukuruan butir percontoh diketahui untuk penggerusan selama 20, 30 dan 50 jam adalah D90 masing-masing 1569,40nm; $784,10 \mathrm{~nm}$ dan $54,30 \mathrm{~nm}$.

Setelah mengalami penggerusan selama 50 jam, percontoh masih didominasi oleh keberadaan unsur Fe di seluruh bagian tubuh bijih, sedangkan keberadaan unsur pengotor Al dan Si juga terlihat hampir di seluruh bagian tubuh bijih dan saling terikat (Gambar $10)$.

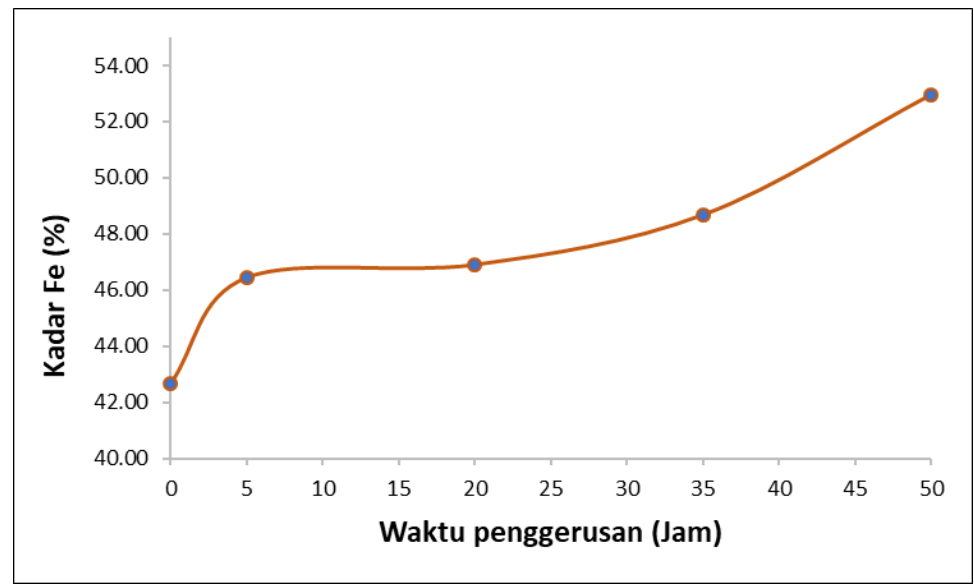

Gambar 8. Grafik hubungan antara waktu penggerusan terhadap kadar Fe

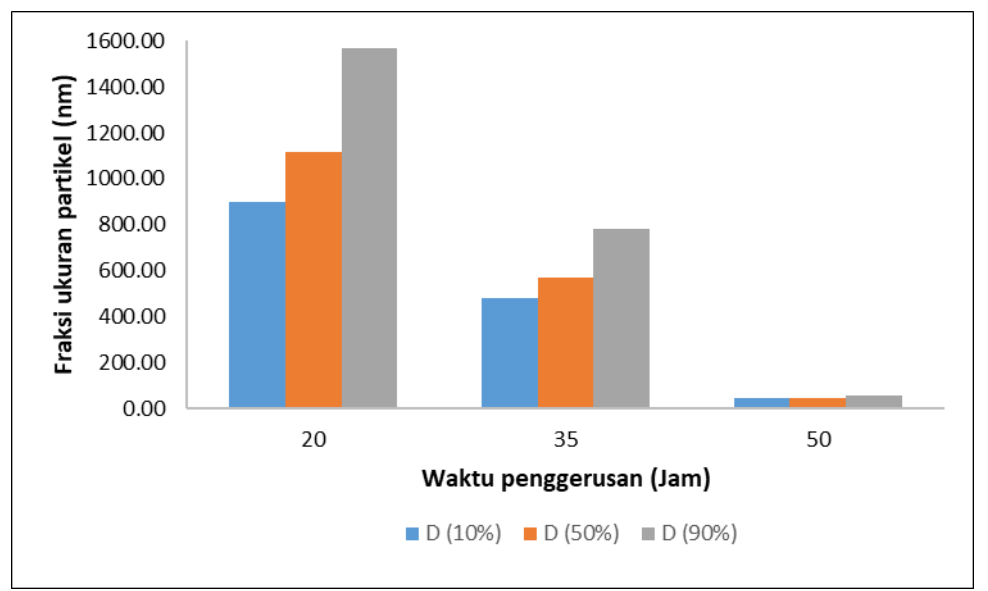

Gambar 9. Grafik hubungan antara waktu penggerusan terhadap distribusi fraksi ukuran partikel 


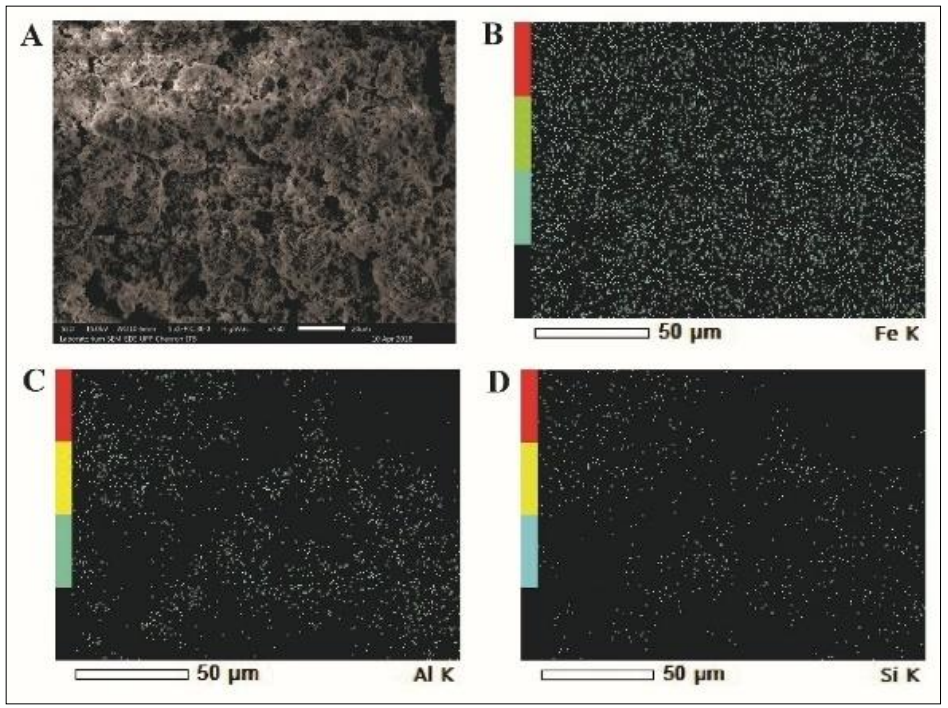

Gambar 10. Hasil SEM-EDS mapping bijih besi laterit setelah 50 jam penggerusan

Hasil analisis VSM percontoh bijih besi laterit mentah, setelah penggerusan 20 dan 50 jam disajikan pada Gambar 11. Terlihat bahwa percontoh bersifat ferromagnetik dengan nilai magnetisasi 6,23 emu/gram, begitu juga pada percontoh setelah mengalami penggerusan selama 20 dan 50 jam dengan nilai magnetisasi masing-masing adalah 6,92 dan 9,55 emu/gram. Hal ini menunjukkan bahwa semakin lama proses penggerusan, sifat kemagnetan bijih besi laterit akan semakin meningkat yang terjadi karena luas permukaan partikel yang besar memberikan intensitas medan magnet yang besar (Lemine, 2014), peningkatan medan magnet disebabkan oleh persentase spin-spin dominan magnet meningkat (Pauzan $d k k$. , 2013).

\section{Pengaruh Persen Volume Mill Terhadap Kadar}

Pada Gambar 12 terlihat bahwa persen volume terbaik pada persen volume mill $50 \%$. Kondisi ini dikarenakan ruang tumbukan antara bola gerus semakin terisi sehingga meningkatkan interaksi antara bola gerus dengan material. Saat semua ruang tumbukan terisi secara efektif oleh bubuk material, laju penggerusan mencapai nilai maksimun (Ikhwanto, 2015).

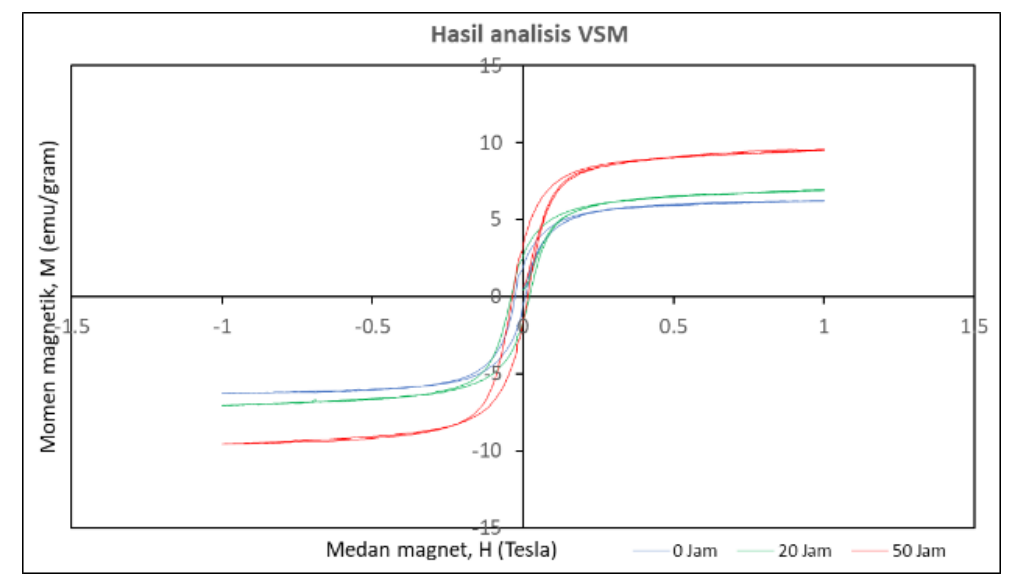

Gambar 11. Hasil analisis vibrating sample magnetometer (VSM) 


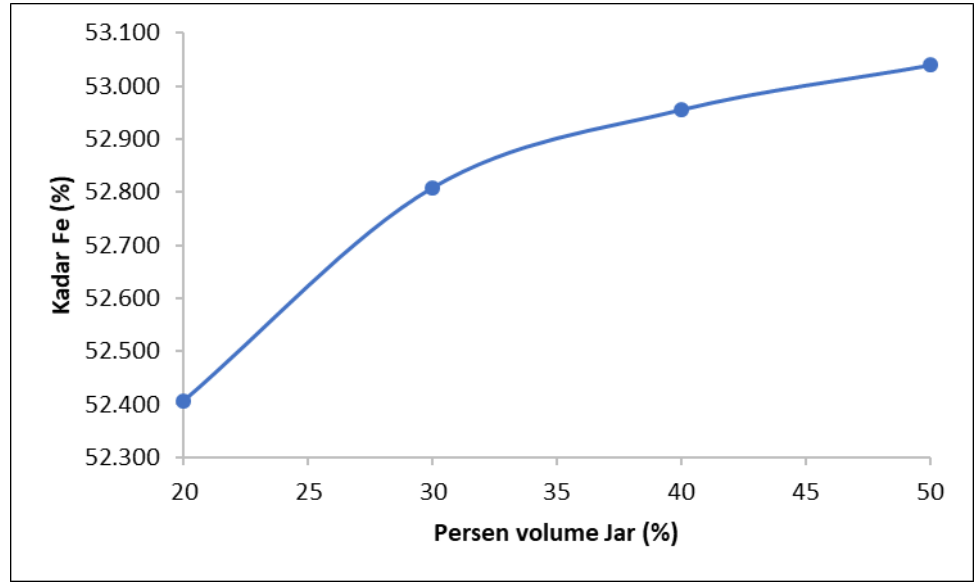

Gambar 12. Grafik hubungan antara persen volume mill dengan kadar unsur Fe

\section{Pengaruh Jenis Media Bola Penggerus Terhadap Kadar}

Tabel 2. Perbandingan hasil analisis XRF antara jenis media penggerus

\begin{tabular}{lcccc}
\hline \multicolumn{1}{c}{ Media Bola } & $\mathrm{Fe}(\%)$ & $\mathrm{Al}(\%)$ & $\mathrm{Si}(\%)$ & $\mathrm{Ni}(\%)$ \\
\hline Bola Baja & 53,039 & 3,351 & 0,731 & 1,04 \\
Bola Keramik & 47,873 & 6,123 & 0,882 & 0,998 \\
\hline
\end{tabular}

Tabel 2 menunjukkan bahwa dengan penggerusan menggunakan media bola-bola baja, kadar unsur Fe sedikit lebih besar dibandingkan dengan menggunakan bola keramik. Hal ini terjadi karena media bola baja memiliki konduktivitas panas yang lebih besar dan mekanisme hantaran panas yang dominan pada baja sedangkan elektron di keramik sebagian besar terlokalisasi (Ismunandar, 2004). Konduktivitas yang lebih besar akan lebih mempercepat transfer panas ke material sehingga material lebih cepat terhidroksi. Hal ini akan berbanding lurus dengan meningkatnya kadar Fe, karena semakin cepatnya material terhidroksi, ion $\mathrm{OH}$ semakin cepat berkurang.

\section{KESIMPULAN}

Berdasarkan data yang telah disajikan dapat diambil beberapa kesimpulan sebagai berikut:

1. Bijih besi laterit asal Pulau Sebuku, Kalimantan Selatan bersifat magnetik kuat;

2. Bijih besi laterit didominasi oleh goetit $(\mathrm{FeOOH})$ dan maghemit $\left(\mathrm{\gamma Fe}_{2} \mathrm{O}_{3}\right)$;
3. Transformasi fasa secara sempurna terjadi setelah 50 jam penggerusan, mineral goetit bertransformasi menjadi hematit dan mineral maghemit bertransformasi menjadi magnetit pada volume mill terbaik 50\% dan penggerusan menggunakan media bola baja dengan peningkatan kadar Fe $53,03 \%$;

4. Selama 50 jam penggerusan didapatkan ukuran partikel D90 54,30 nm;

5. Penggerusan secara mekanokimia berpengaruh pada sifat kemagnetan bijih besi laterit yang semula dengan nilai intensitas medan magnet 6,23 emu/gram menjadi 9,55 emu/gram.

\section{UCAPAN TERIMA KASIH}

Penulis mengucapkan terima kasih kepada Fakultas Teknik Pertambangan dan Perminyakan, Institut Teknologi Bandung dan Pusat Penelitian dan Pengembangan Teknologi Mineral dan Batubara (tekMira) atas izin yang diberikan untuk dapat melakukan keseluruhan percobaan dan analisis.

\section{DAFTAR PUSTAKA}

Chen, Y. H. (2013) "Thermal properties of nanocrystalline goethite, magnetite, and maghemite," Journal of Alloys and Compounds, 553, hal. 194-198. doi: 10.1016/j.jallcom.2012.11.102.

Garg, A. (2014) Why the quality spread on iron ore products is widening, Market Realist. Tersedia pada: 
https://articles2.marketrealist.com/2014/07/w hy-the-quality-spread-on-iron-ore-products-iswidening/ (Diakses: 15 Juni 2019).

González, G., Sagarzazu, A. dan Villalba, R. (2000) "Study of the mechano-chemical transformation of goethite to hematite by TEM and XRD," Materials Research Bulletin, 35(14-15), hal. 2295-2308.

doi: 10.1016/S0025-5408(00)00434-7.

Ikhwanto, M. (2015) Studi kinetika dan karakterisasi produkta grinding terak ferronickel pada variasi bal filling dan rasio jumlah umpan dengan bola gerus. Institut Teknologi Bandung.

Ismunandar (2004) Keramik, kimi@net. Tersedia pada:

http://www.kimianet.lipi.go.id/utama.cgi?artik el\&1100398016\&2 (Diakses: 15 Juni 2018).

Iwasaki, T., Sato, N., Nakamura, H. dan Watano, S. (2013) "An experimental investigation of aqueous-phase synthesis of magnetite nanoparticles via mechanochemical reduction of goethite," Advanced Powder Technology, 24(2), hal. 482-486.

doi: 10.1016/j.apt.2012.11.014.

Kementerian Perindustrian (2017) Pelaku industri ingin formulasi harga gas berbasis produk, www.kemenperin.go.id. Tersedia pada: http://kemenperin.go.id/artikel/18200/PelakuIndustri-Ingin-Formulasi-Harga-Gas-BerbasisProduk (Diakses: 27 September 2017).

Lemine, O. M. (2014) "Transformation of Goethite to Hematite Nanocrystallines by High Energy Ball Milling," Advances in Materials Science and Engineering, 2014, hal. 1-5. doi: 10.1155/2014/589146.

Pardiarto, B. (2011) "Peluang bijih besi dalam pemenuhan kebutuhan komoditas mineral strategis nasional," Buletin Sumber Daya Geologi, 6(2), hal. 59-70. Tersedia pada: http://buletinsdg.geologi.esdm.go.id/index.ph p/bsdg/article/view/BSDG_VOL_6_NO_2_20 11_2.

Pauzan, M., Kato, T., Iwata, S. dan Suharyadi, E. (2013) "Pengaruh ukuran butir dan struktur kristal terhadap sifat kemagnetan pada nanopartikel magnetit (Fe3O4)," in Rosana, D. et al. (ed.) Prosiding Pertemuan IImiah XXVII HFI Jateng \& DIY. Solo: Himpunan Fisika Indonesia, hal. 24-28.

Pusat Sumber Daya Geologi (2016) Executive summary: Pemutahiran data dan neraca sumber daya mineral status 2016. Bandung: Pusat Sumber Daya Geologi. Tersedia pada: http://psdg.geologi.esdm.go.id/images/stories/ neraca/2016/executive summary neraca mineral psdmbp 2016.pdf.

Suratman (2017) "Studi kinetika penghilangan air kristal limonit menjadi hematit pada atmosfer inert," Jurnal Teknologi Mineral dan Batubara, 13(2), hal. 113-123. doi: 10.30556/jtmb.Vol13.No2.2017.204.

Suryanarayana, C. (2001) "Mechanical alloying and milling," Progress in Materials Science, 46(12), hal. 1-184. doi: 10.1016/S00796425(99)00010-9.

Welham, N. J. (1998) "Mechanochemical reduction

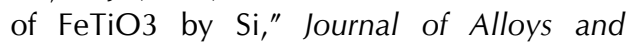
Compounds, 274(1-2), hal. 303-307. doi: 10.1016/S0925-8388(98)00590-8. 